\section{MOVABLE ARTIFICIAL EYES.}

MI. BOISSONNEAU'S ANSWER TO MR. GROSSMITH. To the Elitor of THE LANCET.

Sra,-I have noticed, in a late number of your excellent journal (March 20, 1852), a letter from Mr. Grossmith, who declares himself the author of my method of adapting artificial eyes. I $\mathrm{beg}$, with your permission, to protest against this claim, which probably arises from interested motives. The rights of an inventor must not be trifled with; and as I have chosen England as my adopted country, I an anxious that the truth of my assertions should be placed beyond a doubt.

Mr. Grossuith may call himself the author of the improvements which I have introduced into the art of ocular prothesis, hut it is quite another matter to prove such to be really the case. Mr. G. itates that he has been making hemispherical eyes ever since 1343. He may, no doubt, have seen such eyes at that period, and have admired them so much as at last to fancy himself the inventor of the same; but the following facts will set the question at rest:-

The laborrs which I bestowed upon this peculiar branch of art began in 1822 , and two papers on the subject were presented to learned societies in 1831 and 1840 . In 1841 , I made a public deposit of the new patterns of artificial eves, with descriptive letter-press; and in 1842, the manuscript of the Ancient and Modern History of Artificial Eyes was presented in the same way In 1848 and 1849, my Formulary and Practical Guide were published. These exertions of mine were soon highly appreciated by various scientific bodies, and I received from these, and from different foreign governments, flattering honorary distinctions.

Mr. Grossmith should simply tell us that he is a dealer in artificial eyes; that those he exhibited at the Crystal Palace were made by M. Desjardin, of Paris, who has been dead these three years; and that the feeble and awkward mobility of his eyes does not restore the harmony of the physiognomy, and has no isochronic action. I would then fully believe him; and had he known of the communications to learned bodies above cited (and which I was careful to get registered), he would probably not have raised the pretensi'ns contained in his letter.

As it is important that the most scrupulous accuracy should prevail in scientific matters, and as I am anxious that my method should be extensively known, I beg to offer you an article on the laws which should regulate the shape and adaptation of the artificial eye, so that it may become endowed with prophylactic properties aad isochronic movements. I fully trust that your sense of justice, and your anxiety for the advancement of science, will plead in $m y$ favour, and gain for this letter an insertion in one of your earliest numbers.

I remain, Sir, respectfully yours,

\section{A. Borssonneau,}

Entrusted with the Ocularistic Department of all the Hospitals of Paris.

Princes-street, Carendish-square, March, 1852.

\section{ALLEGED IMPORTATION OF STRYCHNINE.} To the Editor of The Lancer.

SIR-I beg to state that I have found by experiment that one grain of strychnia will give a strong bitter taste to three or four bottles of ale, and will be efficient to even a greater extent. The wholesale price of a grain of strychnia is about a halfpenny. Probably this poison can be manufactured even more cheaply in France. There is, therefore, every inducement for an unprincipled brewer to adulterate his ale with this substance. Of the injurious effects of the long-continued use of such a beverage, there cannot, I think, be a doubt. There is only one remedy for such adulterations-viz., for the legislature to repeal the absurd protection which hop enjoys, and to levy no tax on hops; and to allow any wholesome bitter to be employed. Then I have no doubt that many vegetable bitters would be openly, cheaply, and beneficially employed. Your obedient servant,

$$
\text { Newcastle-on-Tyne, March, 1852, } \quad \text { R. M. GLOVER, M.D. }
$$

** Dr. Glover and the public may feel perfectly confident that the odious allegation made by the French writer, that strychnine is commonly used in this country in the manufacture of bitter beer, is as foul a calumny as was ever invented. It is just possible that a few unprincipled and needy speculators may have resorted to the use of that poisonous drug: but that houses of established reputation and wealth should have employed it in their manufactures, is a supposition far too preposterous to be entertained. Ev. L.
THE COLIEGE OF SURGEONS AND HOMGEOPATHY. To the Editor of 'THE LANCET.

SIR,-The Council of the College of Surgeons have sent the following reply to the memorial of the meeting of the medical men of this town and neighbourhood, praying them to express some opinion on the doctrine and practice of hommopathy.

"College of Surgeons, March 9, 1852.

"Sir,-I am desired to acquaint you that your communication, enclosing copies of resolutions of a meeting of the medical profession of Hull and its neighbourhood, beld in the Hull General Infirmary on the 6th of January last, on the subject of homoopathy, has been laid before the Council of this College, and that the Council, after mature deliberation, consider it inexpedient to interfere in the matter. "I have the homour to be, \&c.,

"EDir. Balfour, Secretary."

The members of College will hence perceive that they must not look to their nominal head for sympathy or assistance in the humiliating contest which they are compelled to maintain with this impudent but successful imposture.

I remain, Sir, your obedient servant,

Hull, March, 1852 . Henry Cooper, M.D.

\section{CONVICTION OF A DRUGGIST FOR ACTING AS AN APOTHECARY.}

Rotherman County Court.-.The Apothecaries' ComPANY y. Crowther. - This case was heard by a special jury, and was listened to with great interest by a court crowded by professional gentlemen, tradesmen, \&e. Mr. Whitfield appeared for the plaintiff, and Mr. Fretson, of Sheffield, defended.

Mr. Whitfield said he appeared on behalf of the Apothecaries' Compans, London, against Mr. James Crow ther, chemist and druggist, Rotherham, and the action was brought to recover the sum of $£ 20$, being a debt or penalty incurred by him for having infringed the act of parliament commonly known as the Apothecaries' Act, passed in the 55th year of Geo. III. The question for the consideration of the jury was, in what consisted the practice of an apothecary? He should prove to the jury that the practice of an apothecary consisted in judging of internal disease from symptoms, and of attending patients, advising, and prescribing, compounding, and supplying medicines; and that the business of a druggist was simply to stand behind a counter, and supply such medicines as he was asked for. He referred to the Apothecaries' Company v. Allen, heard before Lord Denman, at the Lincoln Spring Assizes of 1833 . The defendant in this case was charged with attending patients, advising, making up, and supplying medicines. A verdict was obtained against him on a second trial, but he was not a druggist. The case of the Apothecaries' Company v. Greno, was tried before Judge Maule, in 1839 , and re-heard in the Court of Qneen's Bench, in 1841. It appeared on the trial that the defendant had attended sick persons, administered medicines, and made charges ; and that he was a chemist and druggist. The judge, in directing the jury, said, defendant was acting in the practice of a chemist and druggist, as exercised before the passing of the 55th Geo. III., and a verdict was given for the defendant. A new trial was granted, on the ground of misdirection by the judge on a point of law, and a verdict was obtained for the plaintiff. In the case of the Apothecaries' Company $v$. Lo Tinga, tried at the Darham assizes, in 1843 , the sole question was whether defendant had practised as an apothecary. The counsel for the defence contended that he had supplied the medicines as a chemist. Justice Cresswell (before whom the case was tried) therefore had his attention drawn to this, and he said the province of a chemist was to sell such medicines as he was asked for.-Mr. Fretson said that in the particulars the defendant was charged with attending and prescribing for six persons. He would now call upon his friend to elect which case he would go upon. If the defendant was liable to anything at all, he was liable for $£ 120$, and therefore the court had no jurisdiction unless five of the cases should be withdrawn.--His Honour decided that Mr. Whitfield might give evidence of as many cases as he chose, on consenting to forego all the penalties but one.-Mr. Whitfield proposed to put in as evidence certificates of the cause of death supplied to the registrar of deaths by the defendant, the same as a regular practitioner. - Mr. Fretson objected to the evidence, inasmuch as that was no offence.-The Judge : Not per se, but combined with other facts it may.-Mr. Whitfield contended that the certificates were collateral evidence.-His Honour decided that as Mr. Whitfield did not propose to show that the documents were connected with any patients alleged to have been attended 